AGRICA: Journal of Sustainable Drayland Agriculture, 14 (1): 47-58 (2021)

ISSN-Online: 2715-4955; ISSN-Cetak: 2715-6613

DOI: https://doi.org/10.37478/agr.v14i1.1005

\title{
RESPON PERTUMBUHAN TANAMAN KANGKUNG (Ipomoea aquatica) TERHADAP PEMBERIAN BIOAKTIVATOR
}

\author{
Valentina Purnama Dewi ${ }^{1}$, M. Sodik Yunadi ${ }^{2}$, Sellia Virgia ${ }^{3}$, Wahyu Fajar Saputra ${ }^{4}$ \\ SMKN 63 Jakarta $^{1,2}$, Universitas Indraprasta PGRI ${ }^{3,4}$ \\ Jl. Aselih No.100, Cipedak, Jakarta Selatan, Daerah Khusus Ibukota Jakarta ${ }^{1}$ \\ J1. Nangka Raya No.58 C, Tj. Bar., Jakarta Selatan, Daerah Khusus Ibukota Jakarta² \\ wahyu787@gmail.com
}

\begin{abstract}
Response of The Growth of Kale (Ipomea aquatica) effect of Bioactivator. The purpose of this research was to examine the response of water spinach plants to the application of bioactive fermented liquid organic fertilizer on plant growth. This research used a method consisting of two treatments and one combination, namely a combination of watering and spraying treatments, as well as watering, spraying, and control. This experimen was conducted in the outdoor laboratory of SMKN 63 Jakarta, on land Kale plants. From this research, it was found that the combination of watering and spraying treatments was significantly higher and gave the best results compared to the watering, spraying, and control treatments. Based on the results of the study, it is known that there are differences in harvest age between the treatments of watering, spraying, watering-spraying, and control. The fastest harvesting age in the treatment of watering-spraying. Bioactive has a positive effect on vegetative growth and has a biopesticide effect. This is presumably because bioactive is made from organic material/agricultural waste by aerobic and anaerobic fermentation methods so that from the fermentation it produces amino acids and alcohol which have an effect against plant vegetative growth and pests that often appear on crystal guava and breadfruit plants. During and after the experiment, no signs of pests or diseases were seen on the plants.
\end{abstract}

Key Words :Bioactivator, Kale, Organic Fertilizer

\section{PENDAHULUAN}

Limbah adalah bahan sisa atau buangan yang dihasilkan suatu kegiatan dan proses produksi, dari skala mikro beruparumah tangga, industri, pertambangan, dan lainnya. Menurut Suharto (2011) limbah adalah zat atau bahan buangan yang dihasilkan dari proses kegiatan manusia. Berdasarkan sifatnya limbah dapat dibedakan menjadi dua jenis, yaitu limbah organik dan limbah anorganik. Limbah organik adalah limbah yang dapat diuraikan secara sempurna dengan proses biologi baik secara aerob maupun secara anaerob. Limbah 
organik dapat terurai di tanah melalui proses biologi dan mudah membusuk. Limbah organik biasanya terdiri dari sayuran dan buah yang sudah busuk dan tidak laku dijual atau yang bentuknya hancur saat proses distribusi. Sedangkan limbah anorganik dapat berupa plastik, tas kresek, wadah pembungkus barang yang diperjual belikan di pasar (Siboro et al., 2013). Limbah kota pada umumnya didominasi oleh sampah organik $\pm 70 \%$ sebagai konsekuensi logis dari aktivitas serta pemenuhan kebutuhan penduduk kota. Menurut sumber dan bahan buangannya, sampah organik di perkotaan secara garis besar berasal dari sampah pasar, rumah potong hewan dan restoran serta rumah tangga (Mustadzy et al., 2009). Bahan organik dapat digunakan sebagai pupuk yang berasal dari limbah hasil pertanian dan non pertanian (limbah kota dan limbah industri). Limbah pertanian merupakan sisa dari proses produksi suatu pertanian. Limbah pertanian memiliki potensi cukup besar sebagai pakan ternak dan pupuk organik. Jenis limbah pertanian yang banyak digunakan adalah jerami padi dan batang jagung (Mariyono dan Romjali, 2007). Adapun beberapa bahan organik yang dapat digunakan dalam pembuatan pupuk organik bagi tanaman.

Menurut Hadisuwito (2012:10) Pupuk organik adalah pupuk yang terbuat dari bahan organik atau makhluk hidup yang telah mati. Setelah itu bahan organik ini akan mengalami suatu pembusukan oleh mikroorganisme sehingga sifat fisiknya akan berubah dan berbeda dari semula. Pupuk organik termasuk pupuk yang kandungan unsur haranya lebih dari satu unsur dan mengandung unsur mikro maka dari itu pupuk organik dapat disebut dengan pupuk majemuk. Dalam Peraturan Kementerian Pertanian No. 70/Permentan/SR.140/10/2011 menyatakan bahwa pupuk organik bermanfaat untuk meningkatkan kandungan hara dan bahan organik tanah serta memperbaiki sifat fisik, kimia, dan biologi tanah.Pupuk organik terdapat dalam bentuk padat dan cair.

Menurut Huda (2013) pupuk organik cair mempunyai banyak manfaat diantaranya dapat mendorong dan meningkatkan pembentukan klorofil daun sehingga meningkatkan kemampuan fotosintesis tanaman dan penyerapan nitrogen dari udara, dapat meningkatkan vigor tanaman sehingga tanaman menjadi lebih kokoh dan kuat, untuk meningkatkan daya tahan tanaman terhadap suhu yang kering, merangsang pertumbuhan cabang hasil produksi, meningkatkan pembentukan bakal buah dan bunga, untuk mengurangi gugurnya bunga, bakal buah, dan daun. Pupuk organik cair 
Dewi: Respon pertumbuhan tanaman kangkung terhadap pemberian bioaktivator

dapat kita buat dari beberapa jenis sampah organik yaitu sisa sayur, kulit buah-buahan, buah yang busuk, kulit bawang dan sejenisnya. Menurut Kasmawan (2018) menyimpulkan bahan organik basah seperti sisa buah dan sayuran merupakan bahan baku pupuk cair yang sangat bagus karena selain mudah terdekomposisi, bahan ini juga kaya akan hara yang dibutuhkan tanaman. Pupuk organik cair dapat dibuat dengan menggunakan teknologi pengendalian penguraian secara biologi dari bahan-bahan organik atau disebut dengan komposting secara sederhana .

Bioaktivator dalam istilah dapat didefinisikan sebagai suatu bahan bioaktif yang mampu merombak bahan-bahan organik pada umumnya. Secara spesifik biokativator merupakan isolate mikroba yang dimurnikan serta mempunyai kemampuan secara khusus untuk mencerna bahan organik yang mengandung serat selulosa. Selain dalam mempercepat proses pengomposan, keunggulan dari penggunaan bioaktivator adalah kualitas produk lebih terjamin dan proses produksinya relatif sederhana. Beberapa contoh kelompok mikroba yang mampu merombak bahan selulosa antara lain Trichoderma sp., Pseudomonas, dan Streptomyces (Suwahyono, 2014).
Higa (1994) berpendapat bahwa penggunaan bioaktivator untuk pertumbuhan tanaman di Indonesia dapat berkembang dengan pesat sejak introduksi EM (effective microorganism). Menurutnya pula produk EM berisi berbagai jenis mikroorganisme, terutama bakteri dari kelompok Lactobacillus yang berguna dalam dekomposisi dari bahan-bahan organik. Bioaktivator yang saat ini sering digunakan untuk pembuatan pupuk organik cair adalah EM4. Jalaludin et al. (2016)menyatakan bahwa EM4 merupakan campuran dari mikroorganisme yang menguntungkan. Jumlah mikroorganisme fermentasi di dalam EM4 berkisar 80 jenis.

Bioaktivator EM-4 jenis ini dipilih karena dapat didapatkan dengan mudah dan harga murah serta dapat mempercepat proses fermentasi. Tujuannya untuk mengurangi jumlah limbah sayuran yang menumpuk dengan menggunakannya sebagai bahan baku pupuk organik cair oleh masyarakat luas khususnya petani (Nurfitria et al., 2020). Menurut Nur et al. (2016) Proses pembuatan pupuk organik cair dengan variasi waktu dan variasi penambahan volume EM4 efektif dalam meningkatkan kandungan $\mathrm{N}, \mathrm{P}$, dan $\mathrm{C}$. Semakin lama proses pembuatan pupuk organik cair akan meningkatkan kandungan $\mathrm{N}$, P, dan C. Bioaktivator tumbuhan adalah 
bahan yang mengandung senyawa hidup, biasanya adalah mikroorganisme yang menguntungkan, yang apabila diaplikasikan dalam budidaya tumbuhan dapat berpengaruh pada perbaikan dari tumbuhan tersebut.

Kangkung adalah salah satu tanaman sayuran yang sering dikonsumsi oleh masyarakat. Umumnya tanaman ini mudah tumbuh baik di tanah yang lembab bahkan dalam perairan seperti kolam atau sungai. Tanaman kangkung berasal dari India yang kemudian menyebar ke Birma (Myanmar), Malaysia, Cina Selatan, Australia, Indonesia, dan Afrika. Di negara Cina, tanaman kangkung dikenal sebagai weng cai. Di Negara-negara Eropa, kangkung biasa disebut swamp cabbage, water spinach, atau water convovulus (Vionida, 2012). Menurut Yunianti et al. (2016) pemberian pupuk organik dan anorganik dapat meningkatkan pertumbuhan kangkung seperti tinggi tanaman kangkung, jumlah batang, jumlah daun, indeks luas daun serta hasil tanaman kangkung. Menurut Al dan Sudarsono ( 2004) kangkung dapat tumbuh baik pada semua variasi perlakuan. Pupuk organik yang digunakan, dapat mendukung pertumbuhan kangkung dengan baik. Masa tumbuh tercepat tanaman kangkung ini terjadi antara umur 20 sampai 30 HST artinya masa tumbuh bibit kangkung sangat cepat.Tanaman kangkung dapat tumbuh subur dengan daunnya banyak serta hijau segar, batangnya besar dan lebih keras. Berdasarkan latar belakang yang telah dikemukakan di atas, penelitian ini bertujuan untuk mengetahui respon tanaman kangkung terhadap pemberian bioaktivator.

\section{BAHAN DAN METODE}

Percobaan ini dilakukan di laboratorium terbuka SMKN 63 Jakarta, pada tanaman kangkung darat. Percobaan dilakukan mulai bulan Agustus sampai September 2019. Percobaan ini dilakukan untuk melihat respon tanaman kangkung terhadap pemberian pupuk organik cair fermentasi Bioactive terhadap pertumbuhan tanaman. Rancangan percobaan terdiri dari 4 perlakuanyang diulang sebanyak 3 kali sehingga didapatkan 12 unit percobaan. Adapun 4 bentuk variabel perlakuannya adalah penyiraman (A), penyemprotan (B), kombinasi antara penyiraman dan penyemprotan (C) serta tanpa perlakuan atau variabel kontrol (D).

Masing-masing percobaan mengunakan bedengan tanaman yang berukuran $1 \times 2 \mathrm{~m}^{2}$. dengan tiga ulangan. Aplikasi bioactive dilakukan pada tanaman yang telah berumur 6 hari sejak tanam (daun lembaga muncul). Aplikasi penyemprotan 
Dewi: Respon pertumbuhan tanaman kangkung terhadap pemberian bioaktivator

serta kombinasi penyemprotan dan penyiraman menggunakan dosis $4 \mathrm{~mL}$ bioactive/liter air dan setiap petak mendapat 3 liter campuran. Jumlah larutan semprot saat penyemprotan dilakukan apabila daun tanaman telah basah maka penyemprotan dihentikan. Perlakuan penyemprotan dan penyiraman dilakukan setiap tiga hari sekali.

\section{HASIL DAN PEMBAHASAN}

Rata rata hasil pertumbuhan dan panen pada setiap perlakuan menunjukkan hasil yang berbeda, terlihat perlakuan kombinasi penyiraman dan penyemprotan menunjukkan hasil yang lebih baik dibandingkan perlakuan, penyemprotan, penyiraman saja dan Kontrol . Untuk lebih jelasnya ditampilkan dalam grafik berikut:

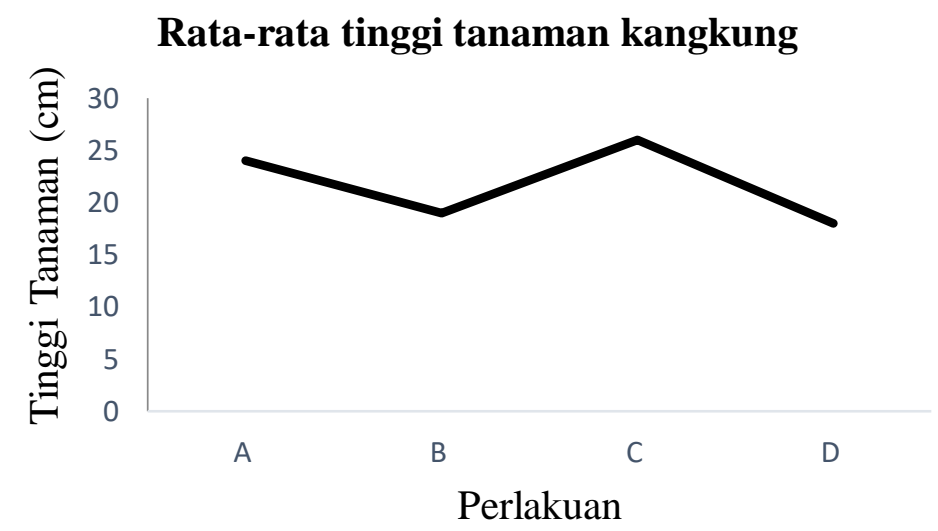

Gambar 1. Rata-Rata Tinggi Tanaman pada Setiap Perlakuan

Ket. A :Penyiraman, B : Penyemprotan, C : Penyiraman dan penyemprotan ,D : Kontrol

Dari data diatas, rata-rata tinggi perlakuan $\mathrm{C}$ menunjukan hasil pertumbuhan tanaman mengalami perbedaan pada tinggi tanaman paling besar dibanding pelakuan A, B, C dan D. Rata-rata tinggi dengan perlakuan yang lain yaitu $26 \mathrm{~cm}$. tanaman pada perlakuan A, B, C dan D Hasil ini terlihat pada Gambar 1 tentang ratasebesar 24, 19, 26, $18 \mathrm{~cm}$. Perlakuan dalam rata tinggi tanaman.

pengamatan ini menunjukan bahwa 
AGRICA, VOL. 14, NO. 1 (2021)

\section{Rata-rata hasil tanaman}

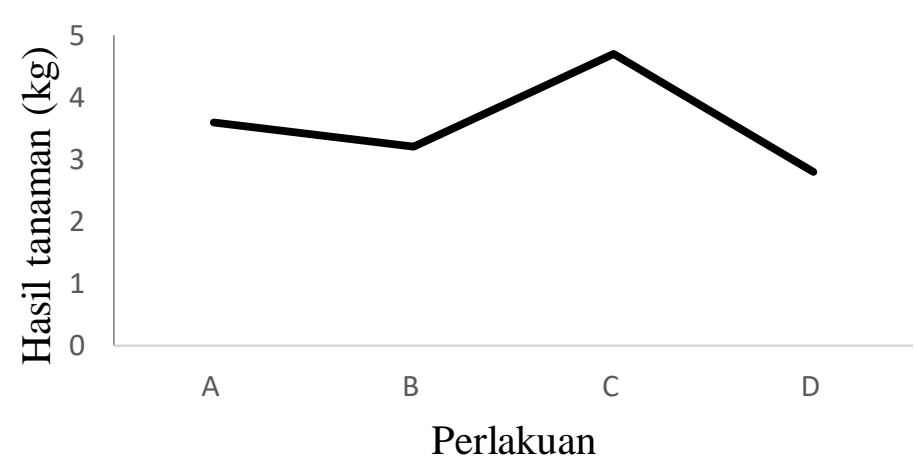

Gambar 2. Rata-Rata Hasil Tanaman pada Setiap Perlakuan

Ket. A :Penyiraman, B : Penyemprotan, C : Penyiraman dan penyemprotan, D : Kontrol

Dari data diatas, rata-rata hasil panen perlakuan $\mathrm{C}$ menunjukan rata-rata hasil tanaman mengalami perbedaan pada panen tanaman paling besar dibanding pelakuan A, B, C dan D. Rata-rata hasil dengan perlakuan yang lain yaitu 4,7 kg. panen tanaman pada perlakuan A, B, C dan Hasil ini terlihat pada Gambar 2 tentang rataD sebesar 3,6;3,2; 4,7; 2,8 kg. Perlakuan rata hasil tanaman. dalam pengamatan ini menunjukan bahwa

\section{Umur tanaman panen}

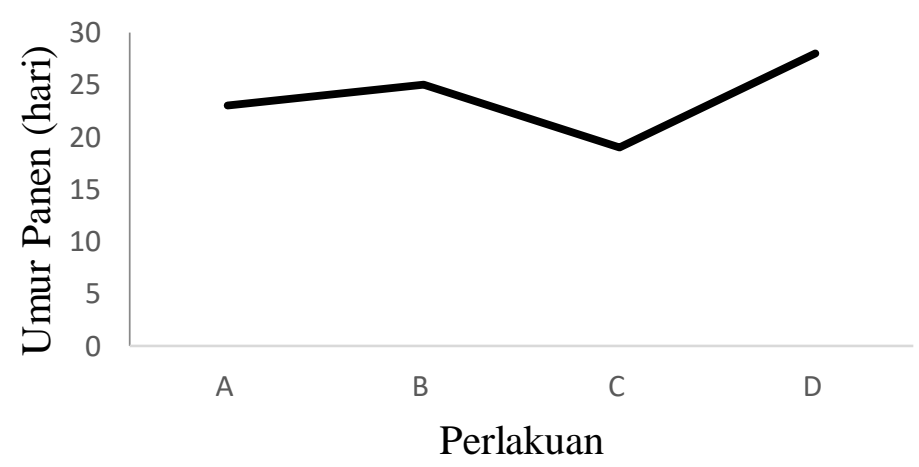

Gambar 3. Rata-Rata Umur Tanaman pada Setiap Perlakuan

Ket. A :Penyiraman , B : Penyemprotan, C : Penyiraman dan penyemprotan ,D : Kontrol

Dari data di atas, rata-rata umur panen panen tanaman pada perlakuan A, B, C dan tanaman mengalami perbedaan pada D sebesar 23, 25, 19, 28 hari. Perlakuan pelakuan A, B, C dan D. Rata-rata umur dalam pengamatan ini menunjukan bahwa 
Dewi: Respon pertumbuhan tanaman kangkung terhadap pemberian bioaktivator

perlakuan $\mathrm{C}$ menunjukan rata-rata umur panen tanaman paling cepat dibanding dengan perlakuan yang lain yaitu 19 hari. Hasil ini terlihat pada Gambar 3 tentang ratarata panen tanaman.

Dari data yang tersebut diatas terlihat bahwa kombinasi perlakuan penyiraman dan penyemprotan (C) nyata lebih tinggi dan memberikan hasil yang terbaik dibandingkan dengan perlakuan penyiraman (A), penyemprotan (B) dan kontrol (D). Perbedaan ini jelas memperlihatkan bahwa tanaman kangkung secara maksimal dapat menyerap unsur hara yang diberikan lewat penyiraman begitu pula dengan penyemprotan didaun sehingga tanaman mendapat hara, baik dari tanah setelah penyiraman maupun dari daun setelah penyemprotan, namun demikian baik penyiraman maupun penyemprotan memberikan hasil yang lebih baik dibandingkan tanpa perlakuan/kontrol. Hal ini sesuai dengan penelitian Utomo (2009) bahwa bioaktivator berpengaruh nyata dalam meningkatkan pertumbuhan tanaman baik itu tinggi tanaman, diameter batang maupun luas daun dalam waktu yang relatif singkat. Pertumbuhan tanaman terbaik diperoleh pada aplikasi perlakuan $\mathrm{C}$ yang menghasilkan tinggi tanaman, diameter batang dan luas daun paling tinggi dibandingkanperlakuan lainnya.

Menurut Baharuddin (2016) pupuk organik mampu meningkatkan aktivitas mikroba tanah, seperti meningkatkan aktivitas enzim tanah dan meningkatkan biomassa mikroba tanah. Pupuk organik yang biasa dikenal masyarakat, seperti pupuk kotoran ayam yang termasuk ke dalam pupuk organik padat dan pupuk organik cair. Sedangkan menurut Syamsiah et al. (2014), penggunaan nitrogen yang mencapai pada batas tertentu dalam jumlah yang banyak akan mengakibatkan produksi tanaman lebih tinggi. Unsur tersebut juga dapat bermanfaat dalam memperbanyak jumlah anakan, mempengaruhi lebar dan panjang daun, mempercepat pertumbuhan meninggi bagi tanaman, serta membuat buah menjadi besar, menambah kadar protein dan lemak bagi tanaman. PGPR (Plant Growth Promoting Rhizobakteri) berperan penting untuk meningkatkan pertumbuhan tanaman, kesuburan lahan dan hasil panen.

Pertumbuhan kangkung darat seperti yang nampak pada Gambar 3 menunjukkan bahwa pertumbuhan tanaman pada umur 21 hst tersebut telah memberikan gambaran kriteria yang secara visual yang mengarah kepada kondisi memungkinkannya kangkung darat untuk layak dipanen. Hal ini telah 
tampak berupa daun yang telah lebat dan pertumbuhan visual batangnya yang baik. Begitu juga hasil gambaran apabila dipanen sudah memberikan tampilan sayuran yang menarik dan secara setelah panen pun layak sebagai bahan yang mudah dikelola dan dipasarkan. Kondisi yang paling penting adalah pertumbuhan tinggi pada tanamannya yang belum terlalu lanjut dan masih dalam kondisi tegak, sehingga akan terhindar dari kondisi rebah dan menjalar. Menurut Leviana et al. (2017), pertumbuhan tanaman semakin meningkat dengan bertambahnya umur tanaman. Hal ini sesuai dengan pendapat Austin (2007) berpendapat dikarenakan semakin lama umur tanaman maka tanaman akan mengalami fase pertumbuhan vegetatif yang cepat. Hal ini juga sesuai dengan pendapat Zulkifli dan Herman (2012) yang menyatakan bahwa pada saat masa vegetatif, tanaman memproduksi hormon pertumbuhan yang lebih banyak sehingga mampu memacu dominasi apikal tanaman, yang selanjutnya meningkatkan tinggi tanaman. Perlakuan dosis pupuk kandang tidak berpengaruh secara dominan terhadap tinggi tanaman.

Berdasarkan data dari hasil panen tanaman kangkung dalam perlakuan $\mathrm{C}$ hasil menunjukan lebih banyak dibanding perlakuan lainnya. Hal ini tidak sebanding dengan penelitian Carora et al. (2014) menunjukkan tidak terjadi interaksi yang nyata antara perlakuan frekuensi dan konsentrasi pemberian bioaktivator terhadap bobot umbi.

Berjalannya fase generatif pada tanaman dimulai dari tanaman mulai berbunga hingga masuknya umur panen (buah sudah matang atau masak). Menurut Haydar et al. (2007), buah yang masak ditentukan oleh beberapa hal antara lain jumlah bunga yang mengalami pembuahan dan persentase buah muda yang dapat tumbuh terus hingga menjadi buah yang masak. Berdasarkan hasil penelitian diketahui bahwa terdapat perbedaan umur panen antara perlakuan A, B, C dan D. Umur panen paling cepat pada perlakuan $\mathrm{C}$, Berdasarkan hasil penelirian sebelumnya menurut Amin (2015), yang didapat perlakuan waktu aplikasi pupuk dua minggu sebelum tanam didapatkan umur panen yang paling cepat dan berbeda nyata dengan perlakuan waktu aplikasi pada waktu tanam, satu minggu setelah tanam dan dua minggu setelah tanam namun berbeda tidak nyata dengan waktu aplikasi satu minggu setelah tanam. Ini sesuai dengan hasil penelitian Marhaeni (2018), yang mengemukakan perlakuan komposisi nutrisi dan pengaturan kepekatan menunjukkan pengaruh interaksi 
Dewi: Respon pertumbuhan tanaman kangkung terhadap pemberian bioaktivator

pada variabel pengamatan umur panen dan pertumbuhan panen. Panen merupakan pekerjaan akhir dari bercocok tanam atau budidaya tanaman, tetapi panen merupakan awal dari pengerjaan pasca panen, yaitu dengan melakukan persiapan untuk penyimpanan dan pemasaran. Perkembangan tanaman menuju panen diantaranya warna hijau tua tetapi tidak terlalu tua, ukuran daun sudah besar dan sudah berkembangan, ukuran batang yang sudah membesar, pada tanaman sayuran sudah mulai berkembang tetapi belum berkembangan.

\section{SIMPULAN}

Berdasarkan hasil dan pembahan didapatkan kesimpulan bahwa bioactive mempengaruhi respon pertumbuhan tanaman kangkung. Hal ini disebabkan bioaktive berpengaruh positif terhadap pertumbuhan vegetatif dan memiliki efek biopestisida hal ini diduga dikarenakan bioactive di buat dari bahan organik/limbah pertanian dengan metode fermentasi aerob dan anaerob sehingga dari hasil fermentasi itu dihasilkan asam amino dan alkhohol yang memiliki pengaruh terhadap pertumbuhan vegetatif tanaman dan hama yang sering muncul pada tanaman kangkung.

\section{UCAPAN TERIMAKASIH}

Dalam penulisan jurnal ini, penulis mengucapkan terima kasih yang sebesar- besarnya kepada PJI (Prestasi Junior Indonesia), SEAMEO BIOTROP, Kepala SMKN 63 Jakarta, guru SMKN 63 Jakarta serta siswa/i SMKN Jakarta yang membantu melancarkan penelitian ini.

\section{DAFTAR PUSTAKA}

Admin. 2018. Cara Membuat Pupuk Organik Cair (POC) Dari Sabut Kelapa Sumber Hara Kalium (K) Alami. pupuklahan.blogspot.com.

AminAdiwirman, Yoseva. 2015. Studi Waktu Aplikasi Pupuk Kompos Leguminosa dengan Bioaktivator Trichoderma Sp. Terhadap Pertumbuhan dan Produksi Tanaman Cabai Merah (Capsicum annuum L.). Jom Faperta Vol. 2 No. 1: 1-15.

Austin, B. and D.A. Austin. 2007. Bacterial Fish Pathogens: Disease of Farmed And Wild Fish, Fourth Edition. Praxis Publishing Ltd. Chicester, UK.

Baharuddin R. 2016. Respon Pertumbuhan dan Hasil Tanaman Cabai (Capsicum Annum L.) Terhadap Pengurangan Dosis Npk 16:16:16 Dengan Pemberian Pupuk Organik. Provinsi Riau. Jurnal Dinamika Pertanian Volume XXXII Nomor 2 Agustus 2016 :115-124. 
AGRICA, VOL. 14, NO. 1 (2021)

Carora K, Y.B Suwasono. 2014. Pengaruh

Pemberian Bioaktivator Terhadap

Pertumbuhan Dan Hasil Tanaman

Bawang Merah(Allium ascolanium

L.). Jurnal Produksi Tanaman Vol. 2

No. 5: 434-442.

Darmawati. 2015. Efektivitas Berbagai

Bioaktivator Terhadap Pembentukan

Kompos Dari Limbah Sayur dan

Daun. Jurnal Dinamika Pertanian

Nomor 2: 93-100.

Djanun Siti. 2019. Cara Membuat Pupuk Organik Cair (Poc) Dari Sabut Kelapa. http://cybex.pertanian.go.id/.

Eka, Leviana, dkk. 2017. Dosis Pupuk Kandang dan Umur Panen Pada

Produksi Baby Kangkung (Ipomoea

Reptans). Journal of Sustainable Agriculture. Vol 32 No. 2:68-74. UNS.

Haydar A., M.A. Mandal, M.B. Ahmed, M.M. Hannan, R. Karim, M.A. Razvy, U.K. Roy, M. Salahin. Jom Faperta Vol 2 No 1 Februari 2015 2007. Studies on genetic variability and interreleationship among the different traits in tomato (Lycopersicum esculentum Mill). Middle-east journal of scientific research 2 Vol. 3: 134-142.
Higa, T and J. Parr. 1994. Beneficial and effective microorganisms for a sustainable agriculture and environment.

http://www.agriton.n1/higa.htm1.

Huda, Muhammad Khoirul. 2013. Pembuatan Pupuk Organik Cair Dai Urin Sapi Dengan Aditif Tetes (Molasse) Metode Fermentasi. Skripsi. Semarang : Universitas Negeri Semarang.

Indriani. 2004. Membuat Kompos secara Kilat. Penebar Swadaya. Jakarta.

Jalaludin, Nasrul Z.A., dan Rizki, S. 2016. Pengolahan Sampah Organik Buahbuahan menjadi Pupuk dengan Menggunakan Efektif Mikroorganisme. Jurnal Teknologi Kimia Unimal, Vol. 5 No. 1: 17-29.

Kasmawan. 2018. Pembuatan Pupuk Organik Cair Menggunakan Teknologi Komposting Sederhana. Jurnal Universitas Udayana. Vol 17 No 2. Universitas Udayana. Bali.

Kusumaningsih, Asih. 2019. Cara Membuat Pupuk Organik Cair dari Rendaman Sabut Kelapa. ilmubudidaya.com.

Marhaeni, Ariwati Trisiwi, dkk. 2018. Rasio N-NO3-:P dan Pengaturan Kepekatan 
Dewi: Respon pertumbuhan tanaman kangkung terhadap pemberian bioaktivator

Larutan Nutrisi Untuk Pembungaan

Waluh Berbasis Hidroponik Substrat.

Jurnal Agrotech Res. Vol 2.No 2 : 69-73. UNS.

Mariyono dan E, Romjali. 2007. Teknologi

Pakan Protein Untuk Sapi Potong Agroinovasi Sinar Tani. Edisi 21 - 27

November 2012. No. 3483.

Lingga dan Marsono. 2003. Petunjuk Penggunaan Pupuk. Penerbit Swadaya. Jakarta

Mariyono \& Romjali E. 2007. Petunjuk Teknis Teknologi Pakan Murah Untuk Usaha Pembibitan Sapi Potong. Pusat Penelitian dan Pengembangan Peternakan, Pasuruan.

Melissa Syamsiah dan Royani. 2014. Respon

Pertumbuhan dan Produksi Tanaman Cabai Merah (Capsicum annum L.) Terhadap Pemberian PGPR (Plant Growth Promoting Rhizobakteri) dari Akar Bambu dan Urine Kelinci. Jurnal Agroscience. Vol. 4 No. 2. Universitas Suryakencana. Cianjur.

Mustadzy M, Rahmi Z, Nusantoro P. 2009. Pemanfaatan Sampah Organik Kota Menjadi Pakan Ikan Patin. Yayasan Pendidikan Mufa Dirgantara Juanda. Bandung.
Nur, Thoyib,dkk. 2016. Pembuatan Pupuk Organik Cair Dari Sampah Organik Rumah Tangga Dengan Penambahan Bioaktivator EM4 (Effective Microorganisms). Konversi, Vol. 5 No. 2 : 5-12. Universitas Lambung Mangkurat : Banjarmasin.

Nurfitria, Nia, dkk. 2020. Analisa Kualitas Pupuk Organik Cair Berbahan Baku Limbah Sayuran Pasar Baru Kabupaten Tuban. Jurnal Agrifarm. Vol 9 No 1. Widya Gama Mahakam. Samarinda.

Peraturan Menteri Pertanian Nomor 70/Permentan/SR.140/10/2011.Pupuk Organik, Pupuk Hayati Dan Pembenah Tanah. Lampiran I, Persyaratan Teknik Minimal Pupuk Organik Padat.

Prayoba. 2017. Aplikasi Biochar, Bioaktivator, dan Biokompos Terhadap Pertumbuhan dan Peningkatan Produksi Tanaman Kedelai (Glycyne Max (L) Merr.) di Lahan Kering[Thesis]. Universitas Mataram. Nusa Tenggara Barat [Indonesia].

Siboro, E.S, Surya, E., dan Herlina, N. 2013. Pembuatan Pupuk Cair dan Biogas dari Campuran Limbah Sayuran. 
AGRICA, VOL. 14, NO. 1 (2021)

Jurnal Teknik Kimia USU. Vol. 2 No. 3: $40-43$.

Suharto. 2011. Limbah Kimia dalam Pencemaran Udara dan Air. Yogyakarta: ANDI.

Suwahyono U, 2014. Cara Cepat Buat Kompos Dari Limbah.Penebar Swadaya. Jakarta.

Umi Trisnawati, dkk. 2018. Pengaruh Pemberian Bioaktivator Terhadap Pertumbuhan dan Hasil Tanaman Sawi (Brassica juncea L.). Jurnal Produksi Tanaman Volume 6. No. 10 : 2423-2430.

Utomo. 2009. Pemanfaatan Beberapa Bioaktivator Terhadap Peningkatan
Laju Dekomposisi Tanah Gambut dan Pertumbuhan Roxb. Jurnal Penelitian Hutan Tanaman Vol. 7 No. 1: 33-38.

Vionida. 2012.Kangkung, Si Antiracun . https://vionida.wordpress.com/2012/0 5/05/kangkung-si-antiracun.

Yunianti, Ika Ferri, dkk. 2016. Pengaruh Pemberian Pupuk Anorganik dan Organik Terhadap Pertumbuhan dan Hasil Tanaman Kangkung di Lahan Tadah Hujan. Prosiding Seminar Nasional Membangun Pertanian Modern dan Inovatif Berkelanjutan dalam Rangka Mendukung MEA hal. 455-459. Kementerian Pertanian Republik Indonesia. 